\title{
PELATIHAN PENGOLAHAN NUGGET LELE BAGI MASYARAKAT DESA GELANG SIDOARJO
}

\author{
${\text { Fenny } \text { Fitriani }^{1)} \text {, Ulaivia Imaniska }}^{2)}$, Ingga Lastari Faustiar ${ }^{3)}$, Evitrianti Mudjihartik ${ }^{4)}$ \\ ${ }^{1,2}$ Fakultas Keguruan dan Ilmu Pendidikan, Universitas PGRI Adi Buana Surabaya \\ ${ }^{3,4}$ Fakultas Ekonomi, Universitas PGRI Adi Buana Surabaya \\ Email: ${ }^{1}$ fenny_f@unipasby.ac.id, ulaiviaimaniska@gmail.com ${ }^{2}$
}

\begin{abstract}
Abtsrak
Salah satu bentuk budidaya yang dilakukan oleh warga di Desa Gelang adalah budidaya lele dengan jenis lele yang dibudidayakan adalah lele dumbo. Seluruh hasil dari budidaya terebut hanya dijual secara langsung kepada pemesan tanpa adanya pengolahan. Untuk dapat meningkatkan penghasilan warga dengan menggunakan bahan baku hasil budidaya maka dilaksanakan program pengabdian masyarakat dengan sasaran warga desa Gelang Tulangan. Pengabdian kepada masyarakat yang dilaksanakan adalah dengan memberikan pelatihan pengolahan nugget lele bagi warga desa Gelang. Hasil dari pengabdian di desa Gelang adalah adanya peningkatan pengkonsumsian ikan lele pada anak-anak dan meningkatnya penghasilan warga dengan hasil penjualan olahan ikan lele berupa nugget
\end{abstract}

Kata Kunci: Nugget, Lele, Pengolahan

\begin{abstract}
One form of cultivation carried out by residents in the village of Gelang is catfish cultivation with the varieties is clarias gariepinus. All products from the cultivation are only sold directly to the buyer without processing. To be able to increase the income of residents by using raw materials from cultivation, a community service program was carried out with the aim of the Gelang Tulangan villagers. Community service is carried out by providing training in processing catfish nuggets for Gelang villagers. The purpose of community sevice is to be able to increase in the consumtion of catfish in children and an increase in the income of residents with the sale of processed catfish in the form of nuggets.
\end{abstract}

Keywords: Nugget, Catfish, Processing

\section{PENDAHULUAN}

Ikan merupakan salah satu sumber protein hewani yang diperlukan oleh tubuh. Selain protein, zat lain yang terkandung dalam ikan dan dibutuhkan oleh tubuh adalah vitamin, lemak, dan mineral (Pratisti, 2017). Hal tersebut menyebabkan perlunya mengkonsumsi ikan secara teratur. Salah satu ikan yang mudah untuk dibudidayakan adalah ikan lele. Kemudahan pembudidayaan lele disebabkan karena lele merupakan salah satu ikan air tawar yang dapat bertahan hidup pada tempat kritis seperti sungai, kolam ikan baik yang subur maupun yang keruh, rawa, sawah, dan tempat berlumpur yang kekurangan oksigen.
Kemampuan ikan lele yang dapat hidup ditempat kritis tersebut disebabkan oleh alat pernafasan tambahan berupa Arborecent. Hal ini menyebabkan pembudidayaan lele dapat dilakukan ditambak air payau dengan kadar garam yang tidak terlalu tinggi.

Jenis ikan lele yang sering dibudidayakan di Indonesia antara lain ikan lele jenis Clarias Batrachus L, ikan lele jenis Clarias Melanoderma Blkr, ikan lele jenis Clarias Leiacanthus Blkr, ikan lele jenis Clarias Nieuhofi $C V$, dan ikan lele jenis Clarias Teysmani Blkr. Akan tetapi ikan lele jenis Clarias Batrachus $L$ merupakan ikan lele yang paling sering dijumpai dan dipelihara karena dagingnya yang lezat. 
Selain kelima jenis ikan lele tersebut, jenis ikan lele yang dibudidayakan di Indonesia adalah ikan lele jenis Clarias Gariepinus atau biasa disebut dengan ikan lele dumbo

Salah satu daerah yang melakukan pembudidayaan ikan lele berada di Desa Gelang Kecamatan Tulangan Kabupaten Sidoarjo. Jenis lele yang dibudidayakan warga Desa Gelang adalah ikan lele jenis Clarias Gariepinus. . Pembudidayaan ikan lele dumbo memiliki kelebihan jika dibandingkan dengan pembudidayaan lele lokal. Hal ini disebabkan pertumbuhan lele dumbo lebih cepat apabila dibandingkan dengan pertumbuhan lele lokal dan lebih dapat bertahan hidup dalam perairan yang rendah kandungan oksigennya (Muhammad \& Andriyanto, 2013). Dari hasil pembudidayaan tersebut, warga Desa Gelang mendapatkan penghasilan dengan menjual hasil pembudidayaan tanpa adanya pengelolaan. Hal ini disebabkan telah adanya pembeli tetap terhadap hasil budidaya ikan lele dumbo (Dzulfikri, 2016).

Salah satu upaya yang dapat dilakukan untuk meningkatkan penghasilan warga Desa Gelang terhadap hasil budidaya ikan lele adalah dengan melakukan pengolahan dahulu terhadap hasil budidaya. Jenis pengolahan yang dapat dilakukan adalah mengolah ikan lele menjadi kedalam bentuk nugget. Pemilihan nugget sebagai bahan pengolahan ikan didasarkan pada bentuk dari nugget yang dapat divariasikan dan dapat memperpanjang daya simpan dari khasiat yang dimiliki oleh ikan lele. Nugget dapat bertahan lama apabila disimpan dalam kondisi beku. Selain itu, pengolahan nugget mudah dilakukan.

Beberapa penelitian maupun pengabdian yang telah dilaksanakan dengan memanfaatkan pengolahan nugget antara lain studi mengenai pengolahan nugget dengan bahan dasar tahu dan sayuran (Khatimah, Kadirman, \& Fadilah, 2018), analisis mengenai kesukaan olahan nugget yang disubtitusikan dengan rumput laut dan tepung sagu (Syamsuddin, Lahming, \& Muhammad, 2015), studi mengenai karakteristik kesukaan nugget apabila terdapat penambahan pasta tomat (Wulandari, Suryaningsih, Pratama, Putra, \& Runtini, 2016), pengembangan usaha nugget di Politeknik Negeri Lhokseumawe (Fona, Kurniasih, \& Raudah, 2017) dan kajian mengenai konversi ikan asin kedalam bentuk nugget (Hardoko, Sasmito, Puspitasari, \& Lilyani, 2018)

Pengolahan lele dalam bentuk nugget merupakan salah satu cara yang dapat dilakukan untuk menarik nafsu makan anak agar tetap mengkonsumsi ikan. Hal ini perlu dilakukan karena mengkonsumsi ikan sangat penting bagi pertumbuhan anak. Karena didalam ikan mengandung DHA yang baik dalam perkembangan otak anak (Ulya, M, Artanti, Kusumawardhani, \& Sa'adah, 2015). Pada penelitian tersebut, diketahui bahwa tingkat pengkonsumsian ikan pada anak masih rendah dikarenakan masih adanya anggapan bahwa ikan merupakan penyebab alergi dan gatal pada anak.

Mempertimbangkan kurangnya konsumsi ikan pada anak dan peningkatan pendapatan warga Desa Gelang, maka warga dengan pelaksana pengabian kepada masyarakat (PKM) memandang perlu mengadakan kegiatan PKM yang melibatkan warga di Desa Gelang. Warga Desa Gelang sangat antusias dengan kegiatan yang dilakukan untuk mencari solusi dalam mengatasi nafsu makan anak yang rendah apabila diminta mengkonsumsi ikan dan solusi mengenai salah satu upaya agar hasil budidaya ikan yang dilakukan oleh warga tidak hanya dijual secara langsung kepada pembeli, tetapi dapat dijual dengan melalui proses pengolahan terlebih dahulu.

\section{METODE PELAKSANAAN}

Pelaksanaan PKM ini terbagi atas tiga tahapan yaitu tahapan perencanaan kegiatan, tahapan pelaksanaan kegiatan, dan tahapan evaluasi kegiatan. Kegiatan yang dilakukan pada tahap perencanaan antara lain melakukan survey lapangan yang dilakukan dengan bantuan perangkat desa mitra, melakukan analisis permasalahan, merancang kegiatan yang akan dilakukan, merancang solusi dari permasalahan yang didapatkan, dan merancang jadwal kegaiatan. 
Kegiatan yang dilakukan pada tahap pelaksanaan antara lain melakukan sosialisasi pengembangan produk olahan ikan lele yang akan dijadikan nugget dan pelatihan atau demonstrasi pembuatan produk olahan ikan lele menjadi nugget dengan memanfaatkan hasil budidaya ikan lele di Desa Gelang Kecamatan Tulangan. Kegiatan evaluasi yang dilaksanakan adalah dengan dilakukan penilaian antusiasme warga terhadap kegiatan PKM dan hasil perubahan pengkonsumsian ikan pada anak.

\section{HASIL DAN PEMBAHASAN}

\section{a. Sosialisasi pengembangan produk olahan ikan lele yang akan dijadikan nugget}

Pelaksana kegiatan PKM mengadakan sosialisai terhadap warga Desa Gelang tentang pengolahan yang dapat dilakukan dari hasil budidaya ikan lele sehingga hasil budidaya yang tidak langsung di jual tanpa ada pengolahan kepada pembeli. Kegiatan sosialisasi ini dilaksanakan sebanyak dua kali di balai desa Gelang Tulangan. Sosialisasi pertama dilaksanakan tanggal 2 Februari 2019 pada jam 09.00 sampai selesai dengan peserta sosialisasi adalah warga dusun Gelang dan sosialisasi kedua dilaksanakan pada tanggal 2 Februari 2019 pada jam 16.00 sampai selesai dengan peserta sosialisasi adalah warga desa dusun Karang Ploso.

Pada kegiatan sosialisasi ini, warga desa Gelang dikenalkan mengenai produk olahan apa saja yang dapat dibuat dengan menggunakan bahan dasar ikan lele dan penjelasan mengenai potensi penjualan hasil olahan jika dijual dipasaran.

\section{b. Pelatihan atau demonstrasi pembuatan produk olahan ikan lele menjadi nugget dengan memanfaatkan hasil budidaya ikan lele}

Setelah kegiatan sosialisasi, pelaksana kegiatan PKM memberikan pelatihan dalam pembatan produk olahan dari hasil budidaya ikan lele menjadi nugget. Pelatihan dilaksanakan sebanyak dua kali, yaitu pada tanggal 3 Februari 2019 bertempat di balai desa Gelang dengan peserta warga dusun
Gelang dan pada tanggal 9 Februari 2019 bertempat di balai desa Gelang dengan peserta warga desa dusun Karang Ploso.

Kegiatan pelatihan diikuti oleh 20 ibuibu PKK dari dusun Gelang dan 25 ibu-ibu PKK dari dusun Karang Ploso. Pada saat dilakukan pelatihan pembuatan olahan ikan lele, ibu-ibu PKK antusias untuk mengikuti langkah-langkah bagaimana cara mengolah ikan lele menjadi nugget. Ibu-ibu PKK diberikan kesempatan untuk mencoba mengolah ikan lele dengan menggunakan bahan-bahan yang telah disediakan oleh tim pelaksana PKM.

\section{c. Evaluasi kegiatan PKM}

Dari hasil pengabdian kepada masyarakat yang telah dilaksanakan, diketahui bahwa para peserta pelatihan tidak terfikirkan untuk mengolah ikan lele kedalam bentuk makanan olahan berupa nugget. Hal ini didasarkan pada tekstur dari ikan lele yang cenderung berminyak, sehingga tidak terfikirkan oleh peserta pelatihan bahwa lele dapat diolah kedalam olahan berbentuk nugget.

Tanggapan yang diberikan setelah kegiatan pengabdian adalah $60 \%$ dari ibu-ibu PKK peserta pelatihan memberikan masukan kepada tim pelaksana PKM bahwa tingkat pengkonsumsian ikan lele anak-anak meningkat. Hal tesebut sesuai dengan hasil angket yang dibagikan kepada masyarakat desa Gelang. Rata-rata konsumsi ikan lele pada anak-anak sebelum dilaksanakan pengabdian sebanyak satu ikan lele setiap minggu dan rata-rata konsumsi ikan lele setelah dilaksanakan pengabdian sebanyak 3 ikan lele setiap minggu. Pada angket tersebut didapatkan keterangan bahwa, peningkatan ini disebabkan karena anak-anak merasa tidak bosan dengan olahan lele yang dibuat.

Selain itu, terdapat tanggapan dari peserta pelatihan bahwa hasil olahan ikan lele yang dijadikan sebagai nugget tersebut menjadi salah satu olahan yang dijual kantin sekolah yang dikelola oleh peserta pelatihan. Dengan adanya tambahan variasi tersebut, keuntungan rata-rata yang diperoleh dari hasil penjualan tersebut meningkat dari $\mathrm{Rp}$ 
65.500,00 per hari menjadi Rp 75.000,00 per hari.

\section{KESIMPULAN}

Dari kegiatan yang telah dilaksanakan dapat disimpulkan:

a. Kegiatan sosialisasi dan pelatihan pengembangan produk olahan ikan lele menjadi nugget dengan memanfatkan hasil budidaya ikan lele yang dimiliki oleh warga berjalan dengan baik dan mendapatkan respon yang baik dari warga desa Gelang yang terdiri atas warga dusun Gelang dan warga dusun Karang Ploso

b. Pelatiahan yang diberikan dapat dijadikan salah satu alternatif pengolahan makanan ikan lele. Alternatif yang diberikan ini menjadi salah satu cara untuk meningkatkan konsumsi ikan pada anak desa Gelang

c. Ilmu yang didapatkan dari pelatihan yang dilaksanakan di pengabian kepada masyarakat ini dijadikan sebagai dasar untuk membuat olahan dari ikan lele yang dapat di jual atau dapat bernilai ekonomis.

\section{REFERENSI}

Dzulfikri, M. A. (2016). Studi Kelayakan Usaha Pembesaran Ikan Lele Di Desa Gelang, Kecamatan Tulangan, Kabupaten Sidoarjo. Malang: Universitas Brawijaya.

Fona, Z., Kurniasih, E., \& Raudah. (2017, November). Pengembangan Unit Usaha Nugget Sehat di Politeknik Negeri Lhokseumawe. Agrokreatif Jurnal Ilmiah Pengabdian kepada Masyarakat, 3(2), 115-122.

Hardoko, Sasmito, B. B., Puspitasari, Y. E., \& Lilyani, N. (2018). Konversi Ikan
Asin Menjadi Nugget Berserat Pangan Dengan Tambahan Ampas Tahu Dan Beberapa Jenis Binder. JPHPI, 21(1), 54-67.

Khatimah, N., Kadirman, \& Fadilah, R. (2018, September). Studi Pembuatan Nugget Berbahan Dasar Tahu dengan Tambahan Sayuran. Jurnal Pendidikan Teknologi Pertanian, 8, S59- S68.

Muhammad, W. N., \& Andriyanto, S. (2013). Manajemen Budidaya Ikan Lele Dumbo (Clarias gariepinus) Di Kampung Lele, Kabupaten Boyolali, Jawa Tengah. Media Akuakultur, 8(1), 63-71.

Pratisti, C. (2017). Model Konsumsi Ikan Pada Konsumen Muda. Jurnal Riset Ekonomi Manajemen (REKOMEN), l(1), 1-15.

Syamsuddin, N., Lahming, \& M. W. (2015). Analisis Kesukaan Terhadap Karakteistik Olahan Nugget yang Disubtitusi dengan Rumput Laut Dan Tepung Sagu. Jurnal Pendidikan Teknologi Pertanian, 1, 1-11.

Ulya, N., M, P. R., Artanti, S., Kusumawardhani, D., \& Sa'adah, U. (2015). Faktor-Faktor Yang Berhubungan Dengan Konsumsi Ikan Pada Anak Usia 1-3 Tahun Di Kota Pekalongan. Jurnal LITBANG Kota Pekalongan, 8, 32-42.

Wulandari, E., Suryaningsih, L., Pratama, A., Putra, D. S., \& Runtini, N. (2016, Desember). Karakteristik Fisik, Kimia dan Nilai Kesukaan Nugget Ayam Dengan Penambahan Pasta Tomat. Jurnal Ilmu Ternak, 16(2), 95-99. 